\title{
International Cooperation and the Reform of Public Procurement Policies $^{1}$
}

\author{
Simon J. Evenett ${ }^{2}$ \\ University of St. Gallen and CEPR
}

Bernard M. Hoekman ${ }^{3}$

World Bank and CEPR

\begin{abstract}
The decision not to launch negotiations in the WTO on three of the Singapore Issues in the socalled July 2004 package provides an opportunity to revisit the knowledge base upon which proposals for further international collective action may be drawn. This paper examines the available evidence on public procurement practices in developing countries that could be relevant to further multilateral rule making on state purchasing. Although there is considerable agreement on ends (efficient, non-corrupt, and transparent public purchasing systems), little information is available on means and, in particular, on the effective and replicable strategies that developing countries can adopt to improve their public procurement systems. A concerted effort to substantially add to the knowledge base on public procurement reforms in developing countries, through targeted research and international exchange of information on implemented procurement policies and outcomes, is critical to identifying areas where further binding multilateral disciplines may be beneficial.
\end{abstract}

JEL classification: F13 and H57.

Keywords: public procurement, state purchasing, discrimination, WTO, Doha Round.

World Bank Policy Research Working Paper 3720, September 2005

The Policy Research Working Paper Series disseminates the findings of work in progress to encourage the exchange of ideas about development issues. An objective of the series is to get the findings out quickly, even if the presentations are less than fully polished. The papers carry the names of the authors and should be cited accordingly. The findings, interpretations, and conclusions expressed in this paper are entirely those of the authors. They do not necessarily represent the view of the World Bank, its Executive Directors, or the countries they represent. Policy Research Working Papers are available online at http://econ.worldbank.org.

\footnotetext{
${ }^{1}$ Some of the material in this paper draws on a report that Evenett prepared for the World Bank on the available empirical knowledge about public procurement reform in developing countries. That report benefited from the comments of Robert Hunja (World Bank) and his team. Evenett would like to acknowledge his gratitude for these constructive comments and suggestions.

${ }^{2}$ Email: simon.evenett@unisg.ch.

3 Email: bhoekman@worldbank.org. This paper was written while visiting the Groupe d'Economie Mondiale, Institut d'Etudes Politiques, Paris.
} 


\section{International Cooperation and the Reform of Public Procurement Policies}

\section{Introduction}

In the July 2004 package, agreed by the World Trade Organization's (WTO's) General Council, it was decided not to launch negotiations on new multilateral rules on transparency in government procurement and, for that matter, on two of the other socalled Singapore Issues (competition and investment policies). In recent years scholarship and commentary has assessed the merits of such negotiations, the causes and likely consequences of the collapse of the 2003 meeting of WTO Ministers in Cancun, and the pre-requisites for and likelihood of reinvigorating the Doha Round. This paper will not revisit these issues. Suffice it to say that the views of analysts, governments, and stakeholders differ substantially. The "breathing space” created by the July 2004 package provides an opportunity to re-evaluate the adequacy of the evidentiary base upon which trade negotiators, policymakers, and others can draw upon when devising and evaluating proposals for new international trade rules.

Evidence matters for at least four reasons. First, a focus on evidence and on the factual record grounds discussions of proposed rules in actual national experience and not on theoretically-inspired "first principles" (be they legal or economic) or on "best practices” whose universal validity is rarely established. Second, a thorough understanding of the relevant magnitudes involved often casts the alleged priorities for multilateral rule making in a different light. Third, proposed rules can be evaluated as to whether they prevent a WTO member from replicating an effective reform (or development) strategy that was pursued by another nation. Fourth and related to this, information is needed on the complementary actions and policies that may need to be implemented so as to ensure that proposed procurement reforms actually benefit the country concerned. In a round of trade negotiations that purports to be pro-development the latter reasons are especially relevant.

In this paper we take one of the Singapore Issues-transparency in government procurement-and describe what is known about the size of developing country 
procurement markets and the trajectories and consequences of procurement reform. ${ }^{4}$ While there is some publicly available information on procurement practices in developing countries, we argue there is not sufficient evidence as to the means by which successful public procurement reform can be implemented. ${ }^{5}$ This in turn makes it difficult to formulate and defend proposals for new multilateral rules in this area. This is not to say that improving transparency is unimportant for public procurement processes-but is it necessarily a priority for developing countries? Did nations that successfully reformed their public procurement practices start by improving transparency or were other steps taken first? Indeed, were measures to improve transparency contingent on other reforms being in place? The case for further multilateral rules on transparency in government procurement will depend, in part, on the answers to these questions.

To date, a convincing, evidence-based case for the incorporation of further binding disciplines in the WTO has not been made. This reflects a lack of analysis and information on the 'return on investment' to alternative types of procurement reforms, the role that international disciplines can and should play, and how such disciplines need to be complemented by national actions to ensure positive payoffs. Compiling such evidence requires the pursuit of a research program to shed light on the success or otherwise of public procurement policies in a range of developing countries.

The paper is organized as follows. Some of the reasons for the increased attention given to public procurement laws and practices in developing countries are discussed in the next section. Section III turns to the factual record on the size of procurement markets in developing economies. Section IV summarizes the findings of the literature on the effects of public procurement reforms, and highlights some of the weaknesses therein. Section $\mathrm{V}$ describes two approaches that could go a considerable way to narrowing the

\footnotetext{
${ }^{4}$ In Evenett and Hoekman (2003) we defined a procurement regime to be transparent if the terms upon which the procurement process is conducted and the criteria on which decisions will be based are properly documented and made widely available; the award decision is made publicly available and motivated; and it is possible to verify that the documented procedures and criteria were applied.

5 This contrasts to the considerable literature on procurement in the Organisation for Economic Cooperation and Development (OECD) nations. See e.g., Arrowsmith and Davies (1998), Arrowsmith and Trybus (2003) and Arrowsmith, Linarelli, and Wallace (2000). A website created by Professor Steven Schooner at http://www.law.gwu.edu/facweb/sschooner/links.html provides an extensive list of links to information on the web devoted to public procurement.
} 
existing knowledge gaps identified in prior sections of this paper. Concluding remarks are presented in section VI.

\section{The growing importance of developing country procurement practices}

Procurement policies are important from a development perspective. Reducing poverty and attaining health, education, and other objectives requires getting the most out of the limited funds available for state purchases of goods, services, and infrastructure. Efficient public procurement practices also contribute towards the sound management of public expenditures more generally (Hunja 2003). Procurement planning enables the identification of major investment expenditures, which in turn facilitates budgetary decision-making. In addition, the effective provision of public services often requires the coordinated delivery of materials and the like, which the state purchasing apparatus must accomplish. It is difficult to imagine how a state can deliver substantial improvements in the well being for its citizens without a public expenditure system that includes effective public procurement policies. This recognition accounts in part for the growing interest in public procurement laws and practices and in the feasibility and likely consequences of their reform.

There is also a growing appreciation of the linkages between specific national objectives and public procurement practices. For example, state contracting is often a central focus of campaigns to tackle corruption and to ensure that appropriate distance is kept between government officials and the private sector. Procurement policies may be part of an industrial policy or an instrument to attain social objectives (e.g., support for small and medium sized enterprises, minority-owned businesses, disadvantaged ethnic groups, or certain geographic regions) through set-asides and preference policies. The manner in which a state implements its public procurement policies has implications for the achievement of such objectives, and for the cost of doing so. Indeed, these policies may speak volumes about numerous other national priorities, practices, and concerns (McCrudden 2004). Knowing what the various objectives are and how effective and efficient procurement policies are in attaining them should be an important dimension of assessing the performance of governments. 
Another reason why procurement issues are attracting increasing attention is that they may condition access to foreign markets. International trade negotiations - whether bilateral, regional, or multilateral—are a mechanism through which governments address the terms upon which foreign firms can compete in domestic public procurement markets. WTO disciplines on procurement are currently voluntary, in that they apply only to signatories of a so-called plurilateral agreement, the Agreement on Government Procurement (GPA). Most developing countries have not joined the GPA, although they have been encouraged to do so by OECD countries. Procurement has also been the subject of negotiated disciplines in numerous bilateral and regional trade agreements, examples being the various treaties associated with the European Community and its successor the European Union, the North American Free Trade Agreement (NAFTA), and recent agreements between the US and EU on the one hand and partner countries (industrialized and developing) on the other.

Given the growing prominence of public procurement law and practices in developing countries the question immediately raises as to what evidence and national experience is available to inform reform strategies and international rule making. As a first step in considering the evidentiary base on public procurement practices in developing countries it is useful to assess the available data on the size of public procurement markets, which is the subject of the next section.

\section{Establishing the factual record: public procurement in developing countries}

Data on total government expenditure levels, in particular on central government outlays, include certain payments (such as compensation for government employees) that are not usually the subject of state contracts with private sector firms or other suppliers. There have been a few attempts to strip out such payments from total government spending levels, so as to provide a more accurate guide of the amount of public outlays that might be influenced by state procurement laws and practices. The latest comprehensive study is

OECD (2002a) which employs the System of National Accounts (SNA) to compute the magnitude of procurement of goods and services by state bodies in 106 developing 
countries in $1998^{6}$. In addition to stripping out expenditures on salaries and wages of state employees, this study differentiates between current government expenditures and capital expenditures. The estimates of the size of the procurement markets are reported (as a share of each nation's respective Gross Domestic Product (GDP)) in Appendix 1.

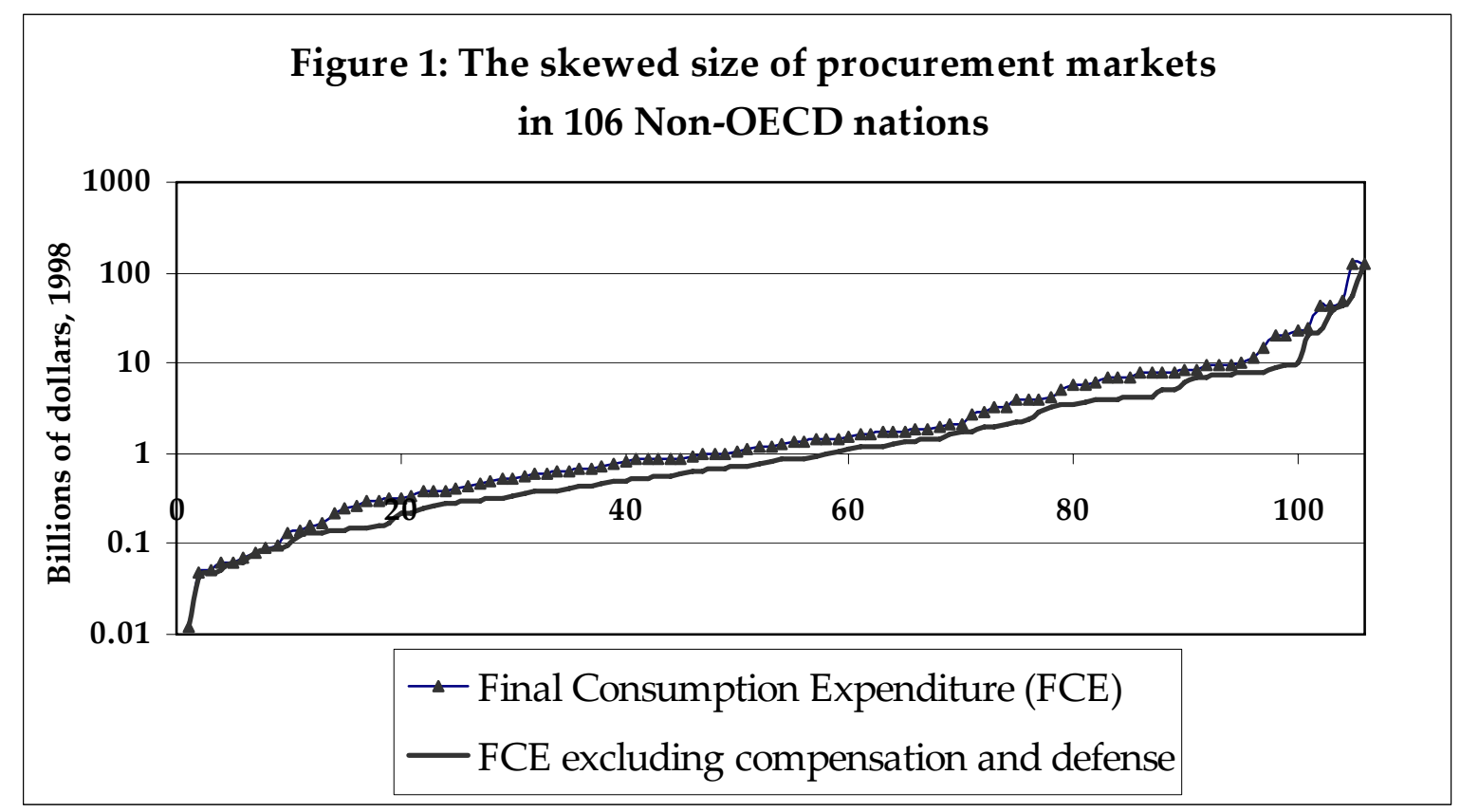

Figure 1 plots the distribution (from smallest to largest) of the computed size of government procurement outlays for the 106 developing economies. The skewed nature of this distribution is clear: in 1998 about half of the developing countries covered in this OECD study had state procurement outlays less than or equal to $\$ 1$ billion. Only six developing countries had state procurement markets ${ }^{7}$ whose total size exceeded $\$ 10$ billion. Table 1 makes clear just how few of the developing countries have public procurement markets that are of any magnitude. This finding raises the question whether there could be a large payoff to OECD firms in improved "market access" to developing countries' state procurement markets. ${ }^{8}$

\footnotetext{
${ }^{6}$ For the purposes of the figure 1 and table 1 reported here a country that is not an OECD member is taken to be a developing country. Separately, it is worth noting that the OECD (2002a) study also reports data on the size of procurement markets in the OECD nations.

${ }^{7}$ See the "FCE excluding compensation and defence" line in Figure 1.

${ }^{8}$ The size of public procurement spending on goods and services may understate the total trade impact of procurement rules. For example, local content requirements for inputs may imply that transactions that do not directly involve a state agency can be influenced by public procurement policies. More generally,
} 
Table 1: Non-OECD procurement markets exceeding US\$5 billion, 1998.

\begin{tabular}{l} 
More than US\$ billion and less than US\$10 billion: \\
Egypt, Morocco, Chile, Peru, Puerto Rica, Bangladesh, India, Israel, Kuwait, Malaysia, \\
Singapore, Syria, United Arab Emirates. \\
\hline More than US\$10 billion: \\
South Africa, Brazil, China, Indonesia, Saudi Arabia, Russia. \\
\hline
\end{tabular}

Source: OECD (2002a).

Taking all of these 106 developing countries together, this OECD study found that government purchases of goods and services in these economies accounted for approximately 5.1 percent of their combined national outputs. (The comparable figure for the OECD member states was 7.9 percent.) The 106 developing countries’ procurement markets amounted to only 13.9 percent of the total worldwide procurement spending in 1998.

The share of total procurement outlays available to international competition is a function of many variables. These include the share of government services that are 'contracted out' to the private sector, the size distribution of contracts (smaller contracts tend not to be attractive to foreign firms), the size of central government as compared to local or municipal governments, and the share of expenditures financed through development assistance funds that are tied to sourcing of goods and services from the donor country, etc. Available data on the relative importance of aid flows as a share of government expenditure suggest that aid finances a significant share of total purchases of goods and services by developing country governments. The ratio of official aid flows (bi- and multilateral) to total expenditure was equivalent to 35 percent of total expenditures on goods and services for low-income countries in the early 1990s. For lower middle-income nations, total aid accounted for 16 percent of expenditures; for upper middle-income economies the figure dropped to 6 percent (Hoekman, 1998).

It is worth noting that very few developing country discriminatory state procurement practices against foreign firms appear to have been the subject of complaints

Evenett and Hoekman (2005) analyze the conditions under which procurement policies affect market access. 
by trade ministries in industrialized countries. Table 2 lists the United States' trading partners that have been cited in annual reports devoted to assessing discriminatory foreign procurement practices. No least developed countries (LDCs) are listed in table 2; only a few of the larger developing countries appear to attract the attention of the United States Trade Representative (USTR) — although one must be open to the possibility that the USTR used the (unfulfilled) threat of "naming" a country in these reports to induce changes in other countries' procurement practices. Even so, there appears little to suggest that the state procurement markets of much of the developing world are large enough to attract much attention from the trade officials in leading industrialized countries.

Table 2: Public procurement practices of countries cited as concerns in USTR annual reports on discriminatory trade practices

\begin{tabular}{|c|c|c|}
\hline \multirow{2}{*}{$\begin{array}{l}\text { Date or } \\
\text { year the } \\
\text { report was } \\
\text { published. }\end{array}$} & \multicolumn{2}{|c|}{$\begin{array}{c}\text { Countries mentioned in the United States' Annual Report on Discrimination in Foreign } \\
\text { Government Procurement. }\end{array}$} \\
\hline & $\begin{array}{l}\text { "Identified" cases of } \\
\text { discrimination. }\end{array}$ & $\begin{array}{c}\text { "Issues of Particular Concern That Do Not Meet the } \\
\text { Criteria for Identification.” }\end{array}$ \\
\hline 1992. & $\begin{array}{l}\text { European Union: } \\
\text { government-owned } \\
\text { telecommunications in } \\
\text { selected member states. }\end{array}$ & \\
\hline $\begin{array}{l}30 \text { April } \\
1996 .\end{array}$ & $\begin{array}{l}\text { Germany: Heavy electrical } \\
\text { equipment. }\end{array}$ & $\begin{array}{l}\text { Japan: Public works. } \\
\text { Japan: Supercomputers. } \\
\text { Japan: Computers. } \\
\text { Australia: Pre-selection criteria for bidders. } \\
\text { Brazil: Expanded discriminatory procedures in } 1994 . \\
\text { China: Non-transparent, closed, and uncompetitive } \\
\text { procedures. }\end{array}$ \\
\hline $\begin{array}{l}30 \text { April } \\
1999 .\end{array}$ & None. & $\begin{array}{l}\text { Korea: Construction of Inchon International Airport. } \\
\text { Japan: Computer products and services. } \\
\text { Japan: Design and consulting and construction } \\
\text { services. }\end{array}$ \\
\hline $\begin{array}{l}30 \text { April } \\
2000 .\end{array}$ & None. & $\begin{array}{l}\text { Japan: Public works. } \\
\text { Taiwan (China): General procurement procedures. } \\
\text { Canada: Provincial price preferences. } \\
\text { Mexico: Implementation of New Procurement Laws } \\
\text { and NAFTA-related tendering periods. } \\
\text { Korea: Airport construction. } \\
\text { Germany: "Sect Filters" (to ensure that the principles } \\
\text { of Scientology are not used or spread in fulfillment of } \\
\text { a contract.) }\end{array}$ \\
\hline $\begin{array}{l}30 \text { April } \\
2001 .\end{array}$ & None. & None in addition to prior years. \\
\hline
\end{tabular}

Source: Website of the Office of the United States’ Trade Representative. 
Turning to actual ${ }^{9}$ procurement laws and their implementation, a small literature has emerged on public procurement practices in developing countries. Table 3 provides a listing of recent studies.

Table 3: List of recent literature on specific instances of public procurement reform in 25 developing economies or assessments of existing procurement policies.

\begin{tabular}{|c|c|c|c|}
\hline $\begin{array}{l}\text { Num } \\
\text {-ber }\end{array}$ & $\begin{array}{l}\text { Economy or } \\
\text { region }\end{array}$ & $\begin{array}{c}\text { Literature (for full citations see the references at } \\
\text { the end of this paper) }\end{array}$ & $\begin{array}{l}\text { Least developed } \\
\text { economy or } \\
\text { region? }\end{array}$ \\
\hline 1. & Bangladesh & Lovei and McKechnie (2000) & Yes \\
\hline 2. & Botswana & Lionjanga (2003) & \\
\hline 3. & Bhutan & Trepte (1998) & Yes \\
\hline 4. & Brazil & $\begin{array}{l}\text { Levy (2001), OECD (2003) (citing Business News } \\
\text { America 2002), and Ozorio de Almeida (2004) }\end{array}$ & \\
\hline 5. & Chile & Orrego-Urzua, Osorio, and Mardones (2001) & \\
\hline 6. & China & $\begin{array}{l}\text { Cao (2003), Tian (2001, 2003), Liu (2004), } \\
\text { Rothery (2003) }\end{array}$ & \\
\hline 7. & Columbia & USAID (1999) & \\
\hline 8. & Czech Republic & Mardas and Varsakelis (2000) & \\
\hline 9. & Estonia & Annikve (1998), Lamvol (2002) & \\
\hline 10. & Ecuador & Moncayo (2004) & \\
\hline 11. & Guatemala & USAID (1999) & \\
\hline 12. & Ghana & Verhage et. al. (2002) & \\
\hline 13. & Hungary & Mardas (2001) & \\
\hline 14. & India & $\begin{array}{l}\text { Srivastava (1999), Khorana (2002), and Das } \\
\text { (2004) }\end{array}$ & \\
\hline 15. & Kenya & Obiri (2003) & \\
\hline 16. & Korea & Choi (1999), Seong and Lee (2004) & \\
\hline 17. & Kosovo & Piselli (2003) & \\
\hline 18. & Laos & Trepte (1998) & Yes \\
\hline 19. & Nicaragua & Cohen (n.d.) & \\
\hline 20. & Nigeria & Ekpenkhio (2003), Onyekpere (2005). & \\
\hline 21. & Pakistan & Transparency International (2002) & \\
\hline 22. & Poland & Glebocki (2000), Piasta (2000), and Lemke (2003) & \\
\hline 23. & South Africa & Wittig (1999), Caron (2002), Watermeyer (2004) & \\
\hline 24. & Tanzania & Nkingu (2003) & Yes \\
\hline 25. & Uganda & Wittig (1999), Agaba (2003) & \\
\hline
\end{tabular}

Notes: This list is based on a search of (i) the websites of the World Bank, OECD, the International Trade Centre, the United Nations Commission on International Trade Law, and the WTO; (ii) the Social Science Research Network database, and (iii) the tables of contents of the leading public procurement journals, including the Public Procurement Law Review and the Journal of Public Procurement, and (iv) recent conferences on public procurement reform in developing countries. This list focuses on the writings of individuals and excludes documents produced by official bodies or reports of international organizations. ${ }^{10}$

\footnotetext{
${ }^{9}$ We are well aware that there is a growing literature of theoretical analyses of public procurement matters and indeed have surveyed such literature in other papers. Here our focus is on studies of actual procurement regimes and procurement reforms in developing countries.

${ }^{10}$ Additional official sources of information on procurement practices include WTO Trade Policy Reviews, especially for members of the GPA at http://www.wto.org/english/tratop_e/tpr_e/tpr_e.htm; submissions to
} 
Even though the 41 articles reported in Table 3 surely do not constitute the entire literature, it is notable that only four focus on the experiences least developed countries. Few studies attempt cross-country comparisons of reform experiences or procurement practices - exceptions being Trepte (1998) for Bhutan and Laos and Wittig (1999) for South Africa and Uganda. Moreover, only a few of the articles ${ }^{11}$ attempt any form of quantification of the costs, benefits, or effects of existing procurement practices or reform proposals.

Another source of information are the Country Procurement Assessment Reports prepared by the World Bank and other development agencies. These reports provide a diagnostic assessment of the strengths and weaknesses of the procurement systems in individual developing countries. ${ }^{12}$ The CPARs that are publicly available are listed in Appendix 2 of this document. The CPAR process has led to recommendations and financing of action plans to modernize or reform existing procurement systems in a number of countries. As is true of the more academic literature, the impact of this work on the performance of national public procurement systems has not been well documented, in the sense that the CPARs tend to focus primarily on legal compliance whether laws and required procedures have been implemented. There is little focus on quantifying performance, the actual return to having applied processes aimed at enhancing competition, transparency and combating the scope for corruption, or the expected return to adopting new procedures that have such outcomes as objectives.

The only cross-country data that is available on the procurement 'performance' of countries are international surveys. An example is the survey of perceptions of

the WTO Working Group on Transparency in Government Procurement Practices, at http://www.wto.org/english/tratop_e/gproc_e/gproc_e.htm; the World Bank's Country Procurement Assessment Reports (not all of which are publicly available); and Individual Action Plans of APEC members, at http://www.apec-iap.org/.

${ }^{11}$ See, for example, Mardas and Varsakelis (2000), Srivastava (1999), Khorana (2002), and Choi (1999). Interestingly, most of these refer to the trade policy-related aspects of procurement reforms-suggesting that empirical analyses of domestic procurement practices are rather thin on the ground.

${ }^{12}$ A CPAR it will typically include an assessment of the legal and regulatory framework for procurement, actual procedures and practices; independent auditing and existence and effectiveness of anti-corruption measures, and procurement performance - whether required procedures are known to participants, are applied, the length of time it takes to complete a transaction, etc. They are typically done jointly with the government and the World Bank, and may also involve a regional development bank (such as the Asian Development Bank or the Inter-American Development Bank. See http://worldbank.org/html/opr/procure/cpar.htm. 
government procurement practices conducted by the World Economic Forum and reported annually in the Global Competitiveness Report. Table 4 presents the average responses (scored on a scale from one to seven) of business people to five questions about public procurement policies in 46 developing countries in 2001. ${ }^{13}$ (The five questions are stated at the top of table 4.) For each of the five questions posed, business people perceive that 10 developing countries fall below the respective 46-country sample average; suggesting that these 10 countries are seen to have poor procurement practices across-the-board. The perception that state officials "favor well connected firms and individuals” is strong in Bolivia, the Dominican Republic, Ecuador, Guatemala, Honduras, and Zimbabwe (all of which score less than two on a scale of one to seven.) Furthermore, "irregular extra payments or bribes connected with public contracts/investment projects” appear to be more prevalent in Bangladesh, Bolivia, Nigeria, Paraguay, the Ukraine, and Zimbabwe (all of which score less than three) than elsewhere.

While only suggestive, the survey responses reveal there is considerable variation in the perceived even-handedness of procurement practices across countries. ${ }^{14}$ This in turn may have implications for domestic and foreign firms' investment decisions. Unfortunately, no information can be distilled from such surveys regarding the extent to which differences in underlying procurement laws and their implementation affect these aggregate perceptions, or how responsive the latter are to reforms. To the best of our knowledge, no one has attempted to answer this empirical question. The paucity of quantitative, cross-country analyses of national procurement practices is striking.

\footnotetext{
${ }^{13}$ For comparison purposes, the mean values of responses in the OECD nations are also reported.

${ }^{14}$ These survey responses have been criticised as subjective, as potentially biased by different cultural norms, and by the fact that few business people are familiar with the procurement policies in many jurisdictions-so raising the question as to how the survey's compilers aggregate across the many respondents' answers when producing summary statistics for a sample of dozens of countries. Yet the reported "average" survey responses are being used more and more often in public discussions and now form part of the empirical (if not factual!) record on national procurement regimes.
} 
Table 4: Business people's perceptions of procurement practices in developing countries, 2001

\begin{tabular}{|c|c|c|c|c|c|}
\hline Non-OECD economy & $\begin{array}{l}\text { The composition of } \\
\text { government spending } \\
\text { in your country (1=is } \\
\text { wasteful, } 7=\text { provides } \\
\text { necessary goods and } \\
\text { services not provided } \\
\text { by the market) }\end{array}$ & \begin{tabular}{|c|} 
Government decisions \\
on the procurement of \\
advanced technology \\
products are based on \\
(1=price alone, \\
$7=$ technology and \\
encouraging \\
innovation)
\end{tabular} & $\begin{array}{l}\text { When deciding upon } \\
\text { policies and contracts, } \\
\text { government officials } \\
\text { (1=usually favor well- } \\
\text { connected firms and } \\
\text { individuals, } 7=\text { are } \\
\text { neutral among firms } \\
\text { and individuals) }\end{array}$ & $\begin{array}{l}\text { New governments } \\
\text { honor the contractual } \\
\text { commitments and } \\
\text { obligations of previous } \\
\text { regimes (1=not true, } \\
7=\text { true) }\end{array}$ & $\begin{array}{c}\text { How commonly do } \\
\text { firms in your industry } \\
\text { give irregular extra } \\
\text { payments or bribes } \\
\text { connected with public } \\
\text { contracts/investment } \\
\text { projects (1=common, } \\
7=\text { never) }\end{array}$ \\
\hline Argentina & 2.2 & 2.9 & 2.7 & 5.0 & 3.1 \\
\hline Bangladesh & 2.7 & 3.0 & 2.1 & 4.1 & 2.1 \\
\hline Bolivia & 2.5 & 2.4 & 1.9 & 2.9 & 2.8 \\
\hline Brazil & 2.7 & 3.9 & 3.0 & 4.2 & 4.0 \\
\hline Bulgaria & 3.2 & 3.5 & 2.8 & 4.3 & 4.4 \\
\hline Chile & 3.9 & 3.8 & 4.0 & 5.3 & 5.3 \\
\hline China & 3.3 & 4.6 & 3.4 & 5.1 & 3.9 \\
\hline Colombia & 2.3 & 3.4 & 2.3 & 3.9 & 3.7 \\
\hline Costa Rica & 2.9 & 3.8 & 3.3 & 4.5 & 4.2 \\
\hline Dominican Republic & 2.7 & 3.4 & 1.9 & 3.2 & 3.9 \\
\hline Ecuador & 2.0 & 2.6 & 1.9 & 3.3 & 3.2 \\
\hline Egypt & 3.9 & 3.6 & 3.8 & 4.9 & 4.4 \\
\hline El Salvador & 3.5 & 3.1 & 2.8 & 4.0 & 3.7 \\
\hline Estonia & 3.6 & 4.5 & 3.3 & 4.8 & 4.4 \\
\hline Guatemala & 2.2 & 2.7 & 1.7 & 2.2 & 3.1 \\
\hline Honduras & 2.2 & 2.4 & 1.8 & 3.6 & 3.2 \\
\hline Hong Kong SAR & 5.5 & 4.4 & 4.5 & 6.3 & 6.1 \\
\hline India & 3.2 & 3.8 & 3.4 & 5.1 & 3.4 \\
\hline Indonesia & 3.1 & 4.0 & 2.6 & 3.8 & 3.0 \\
\hline Israel & 3.7 & 4.5 & 4.1 & 6.1 & 5.9 \\
\hline Jamaica & 3.2 & 3.9 & 2.6 & 4.6 & 4.4 \\
\hline Jordan & 4.3 & 3.9 & 3.8 & 5.4 & 4.8 \\
\hline Latvia & 3.2 & 4.0 & 2.9 & 3.7 & 3.8 \\
\hline Lithuania & 2.6 & 3.4 & 3.3 & 3.5 & 5.7 \\
\hline Malaysia & 4.2 & 4.4 & 3.0 & 4.6 & 3.5 \\
\hline Mauritius & 4.1 & 3.4 & 3.4 & 5.4 & 3.4 \\
\hline Nicaragua & 2.3 & 3.1 & 2.2 & 3.2 & 3.2 \\
\hline Nigeria & 2.7 & 3.7 & 2.0 & 3.7 & 2.3 \\
\hline Panama & 3.2 & 3.3 & 2.3 & 3.7 & 3.4 \\
\hline Paraguay & 1.7 & 2.7 & 2.6 & 2.9 & 2.6 \\
\hline
\end{tabular}




\begin{tabular}{|c|c|c|c|c|c|}
\hline Non-OECD economy & $\begin{array}{l}\text { The composition of } \\
\text { government spending } \\
\text { in your country (1=is } \\
\text { wasteful, } 7=\text { provides } \\
\text { necessary goods and } \\
\text { services not provided } \\
\text { by the market) }\end{array}$ & \begin{tabular}{|} 
Government decisions \\
on the procurement of \\
advanced technology \\
products are based on \\
(1=price alone, \\
$7=$ technology and \\
encouraging \\
innovation)
\end{tabular} & $\begin{array}{l}\text { When deciding upon } \\
\text { policies and contracts, } \\
\text { government officials } \\
\text { (1=usually favor well- } \\
\text { connected firms and } \\
\text { individuals, } 7=\text { are } \\
\text { neutral among firms } \\
\text { and individuals) }\end{array}$ & $\begin{array}{l}\text { New governments } \\
\text { honor the contractual } \\
\text { commitments and } \\
\text { obligations of previous } \\
\text { regimes (1=not true, } \\
7=\text { true) }\end{array}$ & $\begin{array}{c}\text { How commonly do } \\
\text { firms in your industry } \\
\text { give irregular extra } \\
\text { payments or bribes } \\
\text { connected with public } \\
\text { contracts/investment } \\
\text { projects (1=common, } \\
7=\text { never) }\end{array}$ \\
\hline Peru & 2.8 & 2.7 & 2.9 & 3.9 & 4.2 \\
\hline Philippines & 2.8 & 3.4 & 2.7 & 4.8 & 3.0 \\
\hline Romania & 2.5 & 3.3 & 3.7 & 3.2 & 4.1 \\
\hline Russia & 2.5 & 3.6 & 3.7 & 4.0 & 3.8 \\
\hline Singapore & 5.9 & 5.7 & 5.1 & 6.3 & 6.4 \\
\hline Slovenia & 3.3 & 4.2 & 3.5 & 4.5 & 4.1 \\
\hline South Africa & 3.8 & 3.9 & 3.1 & 5.6 & 4.4 \\
\hline Sri Lanka & 2.6 & 3.5 & 2.7 & 4.1 & 4.3 \\
\hline Taiwan & 4.3 & 5.1 & 3.9 & 3.6 & 5.6 \\
\hline Thailand & 4.3 & 4.0 & 3.5 & 4.9 & 3.7 \\
\hline Trinidad and Tobago & 4.1 & 4.0 & 2.7 & 4.8 & 4.2 \\
\hline Ukraine & 2.1 & 3.9 & 2.1 & 2.5 & 2.9 \\
\hline Uruguay & 2.9 & 3.8 & 3.6 & 5.4 & 4.4 \\
\hline Venezuela & 2.2 & 3.1 & 2.6 & 3.9 & 3.5 \\
\hline Vietnam & 3.1 & 4.0 & 3.0 & 3.7 & 3.5 \\
\hline Zimbabwe & 1.4 & 3.3 & 1.9 & 4.1 & 2.5 \\
\hline Mean for these developing countries & 3.1 & 3.6 & 3.0 & 4.3 & 3.9 \\
\hline Mean for the OECD economies & 4.0 & 4.4 & 4.2 & 5.5 & 5.3 \\
\hline
\end{tabular}

Source: The Global Competititiveness Report, 2001-2002. Interview responses to questions above by business people familiar with a given economy. Notes:

number in italics

signifies the reported value is less than the average for those developing countries reported here signifies the reported value is more than the average for the OECD countries surveyed 


\section{Assessments of public procurement reform in developing countries}

Much tends to be claimed for the benefits of procurement reforms. However, there is little analysis whether these benefits were realized after reform initiatives occurred. What follows is a brief assessment of some of the evidence mustered in support of these reforms. This is often anecdotal in nature and generally does not provide policymakers with a sense of the relative costs and benefits of different policy options. Frequently the evidence cannot withstand the rigorous scrutiny that should be applied to policy analyses. This should not be seen as an indictment of the available literature-rather as an opportunity which further analysis could rectify.

Much is claimed in favor of the reform of public procurement practices, as the following rather typical statement about improvements in transparency makes clear:

"Transparent procurement procedures can contribute to a more efficient allocation of resources through increased competition, higher quality procurement and budgetary savings for governments and thus for taxpayers. They can also help attract more investment by lowering risk. Objective and transparent procedures can in addition help enhance the efficiency of local suppliers as they compete for public contracts, thereby improving trade prospects by making these suppliers more competitive exporters.... Finally, transparent procurement procedures can help limit bribery and corruption, which are particularly rampant in the procurement field” (OECD 2003, page 3).

Or, to cite an EC submission to the WTO Working Party in the run up to the Cancun meeting in 2003, benefits of transparency include:

"Efficiency and innovation: Public procurement applied in a transparent environment with a clear set of [predefined] rules defined [... ] may allow tendering companies from both developed and developing countries to foster enhanced competition thus stimulating innovation amongst bidders.

Better value for money: Transparent tendering should lead to effective competition by comparing offers from different bidders. When tenders are to be opened to foreign bidders, the differences in terms of value and quality regularly brings prices down, as in any other auction system. Governments and public entities have a political duty to purchase goods, services and works through the most economically advantageous offer. More transparency in procurement open to foreign suppliers contributes to increased competition and governments obtain lower prices, thereby reducing budget expenditure.

Encouraging investment and partnership: Access to a foreign market when tenders are to be opened to foreign bidders, is always difficult, requiring, as it 
does, previous market research, the setting-up of a distribution system, the opening of local branches and/or the appointing of representatives. It is usually the case for foreign bidders wishing to win a public contract to set up a joint venture or similar partnership with local suppliers who are more familiar with domestic law, rules and procedures thus increasing the chances of success. Transparency will increase investment and partnership.

Reducing corruption: Amongst the different forms of corruption affecting foreign trade (judicial corruption, political corruption), bribery (to officials and politicians) during the tendering process is one of the most significant and distorting of all corruption practices: extra expenditure for public budgets ultimately borne by tax payers, reducing free competition and quality of deliverables, discouraging investment, etc. Publishing calls for tenders, notifying contract awards, including the successful bidder's name and final price, and making award criteria more transparent and accountable are some of the basic principles of transparency in government procurement which directly affect corruption practices." (EC submission to the WTO, WT/WGTGP/W/41, June 2003).

Ideally, the evidence offered in support of such claims would trace through the changes in public procurement policies to some observable outcome and would take into account the other possible non-procurement related factors that might be at work. Much of the evidence actually offered does not meet this standard. Indeed, many of the arguments that are frequently put forth are in fact anecdotes about episodes of procurement reforms dressed up as quantitative evidence see, for example, Box 1.

\section{Box 1. Examples of cost-savings under transparent procurement systems}

- Through the strengthening of transparency and procurement procedures including, for example, eliminating any tender specifications that favor a particular tender, Guatemala's Ministry of Health reports savings of 43 percent on the purchase of medicines.

- The Colombian Ministry of Defense reports generating 47 percent savings in the procurement of military goods through improvement of transparency and procurement procedures.

- Nicaragua had been spending about 17 percent of its health budget on pharmaceuticals. High drug expenditure had resulted from a lack of pricing and drug information and non-transparent procurement procedures. With the establishment of a transparent procurement agency, accompanied by the effective implementation of an essential drug list, the government was able to reduce drug costs significantly. Within one year of introducing these measures, the government had reduced its pharmaceutical budget from \$21 million in 1992 to \$13 million in 1993. 
- In Pakistan, an open and transparent bidding process has resulted in savings of more than Rs 187 million (US \$3.1m) for the Karachi Water and Sewerage Board.

- After introducing transparent procurement procedures in the energy sector, Bangladesh was able to reduce electricity prices to less than US \$0.03 a kilowatthour, roughly half the price of directly negotiated deals in Indonesia.

Source: OECD (2003).

On close inspection, the sources for the Bangladeshi, Columbian, Guatemalan, and Pakistani cases do not provide sufficient data to demonstrate the claims made. ${ }^{15}$ The point here is not to criticize the authors of the OECD study; rather it is to make the point that if procurement reform is to be given a higher profile in national policymaking better studies of actual reform experiences are needed.

Other information is more quantitative in nature and offers some circumstantial evidence that is suggestive of sizeable gains from procurement reforms. Using the OECD (2002a) data on the size of national procurement markets in 1998, one can calculate the dollar value of the savings that would result if procurement reforms yielded a 10 percent reduction in the prices paid by the government on its existing purchases. This gain can then be compared to the amount of aid a given country received in 1998, providing an “equivalent” percentage increase in aid that would free up the same amount of resources as the procurement reform specified above. This calculation provides a sense of how large self-help (that is, domestic procurement reform) compares to current levels of assistance from abroad.

For 39 of the 106 developing countries in the OECD (2002a) study data on aid receipts is reported in World Development Indicators Online. Figure 2 plots the cumulative distribution of the aid "equivalent" of a 10 percent reduction in state expenditures brought about by a potential procurement reform. The findings are quite striking: in all but two developing countries the expansion in aid that would free up as much resources as the stated procurement reform was over 25 percent. In over half the sample of 39 developing countries, the equivalent aid expansion was over 50 percent. In

\footnotetext{
${ }^{15}$ The study supporting the claims made about Nicaraguan pharmaceuticals is not on the internet, and therefore is not easily verifiable. Even if it were available, one would want to know how much of the reported reduction in drug costs was due to implementing a transparent procurement agency and how much due to implementing an "essential" drugs list. The effects of one should not be conflated with the other.
} 
short, these calculations (for that is all they are) suggest that the benefits of a modest procurement reform could be sizeable compared to one frequently discussed source of funding for development; namely, aid. Of course, the critical word in the last sentence is "suggest" as the calculations above do not demonstrate that procurement reforms will generate a 10 percent reduction in the prices paid by the states; nor do they shed any light on what needs to be reformed and how. Nevertheless, by giving some sense of the relevant magnitudes, such calculations may be more credible than the anecdotes often reported in official reports, academic publications, and the like.

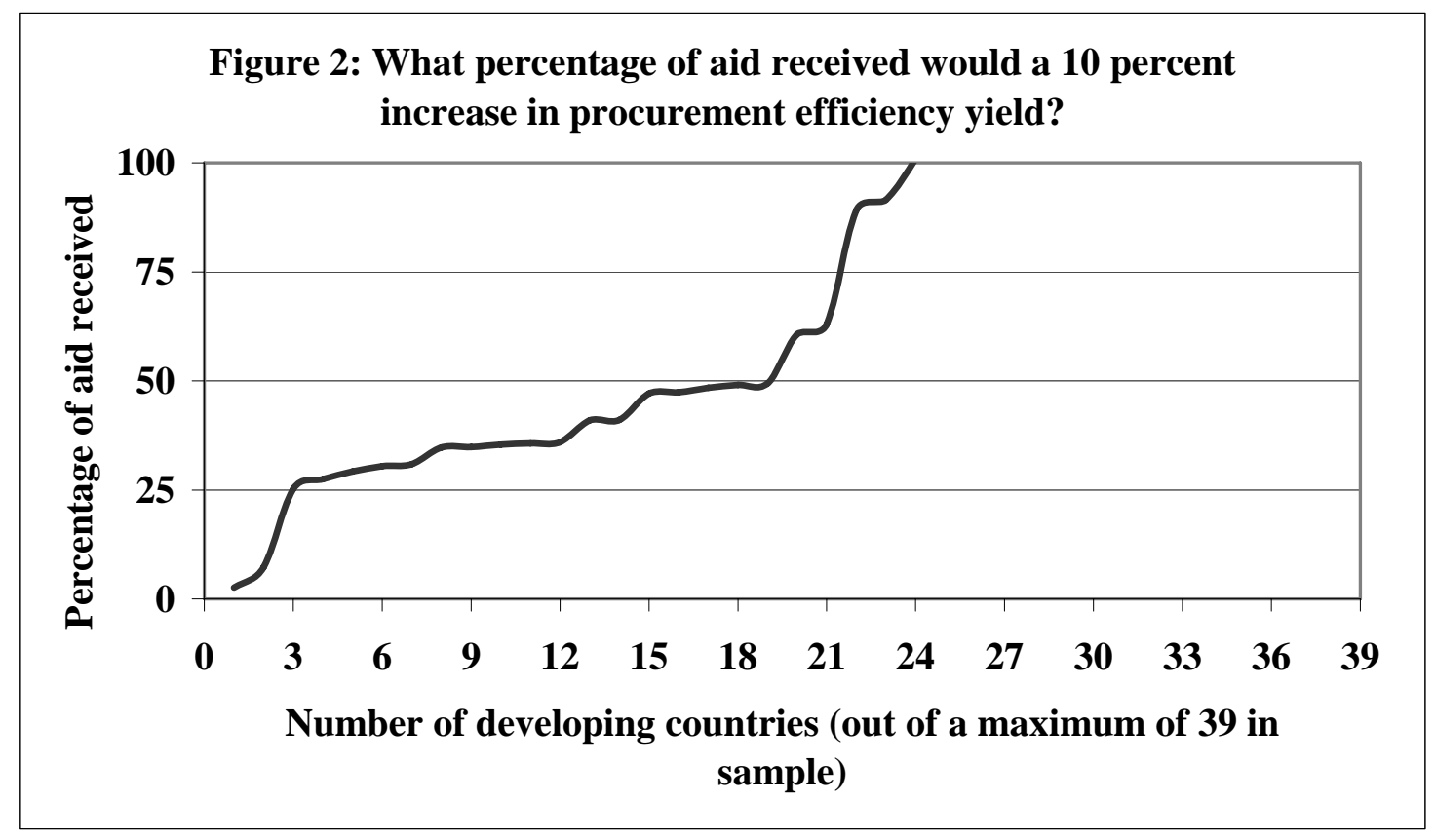

Another type of evidence that is suggestive of the benefits of procurement reform focuses on a positive change in some procurement-related outcome that follows the implementation of a reform. An example of this type of evidence is found in Lemke's (2003) account of Polish experience after a new Public Procurement Law came into force on 1 January 1995. This law mandated the announcement of certain state contracts in a newly created Bulletin of Public Procurement, which is now distributed to potential bidders in paper and in electronic form. Table 5 reports for the years 1996-2001 the number of announcements in this Bulletin and the average number of offers made by contractors for each announcement. The fact that the number of offers rises over time (from 3.64 in 1996 to 5.50 in the first half of 2001) might be thought to support the 
hypothesis that the increased transparency (the publication of announcements) resulted in more bidders for state contracts. Unfortunately, to conclude this one needs to know that some other factor was not responsible for the increased propensity to bid for state contracts. For example, overall economic reforms could have resulted in an across-theboard increase in the number of firms competing in the state procurement market, including trade liberalization resulting in greater imports.

Table 5: Bidders for Polish government procurement contracts, 1996-2001

\begin{tabular}{|l|c|c|c|c|c|c|}
\hline Item & 1996 & 1997 & 1998 & 1999 & 2000 & $\begin{array}{c}2001 \text { (first } \\
\text { half only) }\end{array}$ \\
\hline $\begin{array}{l}\text { Number of announcements in the Bulletin of } \\
\text { Public Procurement }\end{array}$ & 34136 & 44657 & 53147 & 55262 & 70234 & 37983 \\
\hline $\begin{array}{l}\text { Value of contracts announced in the Bulletin } \\
\text { of Public Procurement, (US \$ billion) }\end{array}$ & & 13.6 & 17.5 & 17.7 & 23.0 & 11.1 \\
\hline $\begin{array}{l}\text { Mean number of offers for each } \\
\text { announcement (that resulted in the selection of } \\
\text { an offer.)* }\end{array}$ & 3.64 & 4.16 & 4.70 & 5.40 & 5.15 & 5.50 \\
\hline
\end{tabular}

Note: * Approximately 20 percent of announced procurements were "invalidated"

Source: Lemke (2003, page 119).

Moreover, this evidence alone cannot explain why the average number of bidders for services and supplies contracts fell after 1999-even though the additional transparency brought about by the publication is presumably unchanged (or possibly enhanced if the published announcements became more precise over time.) Furthermore, even if the hypothesis is to be believed, this evidence does not reveal by what percentage (if at all) the prices paid by the state fell as a result of more firms bidding for public contracts. Without such estimates of the resulting savings one cannot compare these benefits with the costs of publishing announcements about procurement opportunities and the costs of verifying their accuracy. To reiterate: the objective of the foregoing discussion is not to criticize any one study or attempt at procurement reform. Rather it is to point out that the available empirical evidence is unsatisfactory for policymaking purposes, and also to indicate what types of questions on procurement practices in developing countries need to be addressed.

The available literature is a stronger on the factors that impede national reform initiatives on public procurement. For the most part, this strand of literature makes no 
claims to be quantitative and so the concerns raised in previous paragraphs do not arise. The first theme of such literature is that developing countries differ markedly in their starting points for procurement reforms (Hunja, 2003), and this can have a considerable bearing on the types and strength of the prevailing vested interests. The transition economies, for example, have had to create from scratch procedures for purchasing from their (often recently developed) private sectors. Other developing countries-with longer traditions of private sector involvement in their economies - have attempted to modernize their procurement practices. The legacy of the past plays a different role in yet another group of developing countries: those former colonies that inherited procurement regimes from their respective former rules and that now seek to update and revise these practices.

Differences in initial conditions also interact with competing influences and pressures to shape the reform process, if any. Typically, domestic initiatives are influenced by international standards (such as the UNCITRAL Model Law on Procurement). External partners and membership of regional trading agreements played an important role in the reforms to the procurement legislation and practice in many Eastern European nations (Hupkes, 1997). This experience raises the general question of whether international guidelines on procurement or regional procurement rules are appropriate for the development needs of low and middle-income countries. ${ }^{16}$ This has a direct bearing to the debate on the merits of WTO disciplines and on the need for further research-points developed in the two following sections.

Turning to the success or otherwise of procurement reform initiatives in developing countries, the experience has been decidedly mixed. Hunja (2003) identifies three major impediments to successful reform: (i) deeply vested interests and the lack of political will to overcome them; (ii) paucity of technical knowledge and capacity; and (iii) the complexity of the substantive issues involved. Faced with these obstacles, some have argued that a necessary condition for reform is strong support from senior political leaders. Others have stressed noted the role that across-the-board, rather than procurement-specific, measures to improve governance can play. The former can

\footnotetext{
${ }^{16}$ For a stimulating contribution on this matter see Schooner and Yulkins (2003).
} 
introduce improvements to procurement indirectly as they do not single out specific entities or procurement officials for special attention (Rose Ackerman 1999).

As noted in Table 1, there is a modest but growing literature on national experience with procurement practices and reforms. Such literature is undoubtedly important in establishing the factual record and relevant institutional set up. However, there has been little attempt to synthesize the lessons learned for policymakers in other developing countries. The fact that the few illuminating cross-country synthesis papers do not motivate their analyses or their recommendations with explicit references to national experience is telling. ${ }^{17}$

Technological developments have added a new dimension to potential procurement reforms in both developing and industrial economies. The combination of greater computing power and cheaper internet-based communication has given rise to socalled e-procurement or electronic procurement regimes. It is an open question how and to what extent state procuring entities can reap the benefits from recent innovations (Segal and Taylor 2001)—much will depend on the extent of the "digital divide" and the quality and cost of the underlying telecom infrastructure in a country. E-procurement offers the promise of cutting costs and simplifying administrative procedures, especially for repetitive transactions and relatively homogeneous products. Promising and innovative mechanisms that revolve around e-procurement have been implemented in countries such as Brazil (Ozorio de Almeida, 2004). In this Brazilian case it has reportedly led to significant cost savings and an increase in the transparency and accountability of government bodies. Moreover, E-procurement can support better statistical reporting, enhanced transparency, and bulk buying (Wiseman 2000). However, implementing these innovations will entail costs (infrastructure, training, etc.) Depending on country circumstances it may also require complementary reforms-e.g., telecommunications regulation, privatization, etc. Concerns have also been raised about privacy and the protection of confidential business information, and the capacity to store data over long time periods. All of these issues are wide open for further research and analysis.

\footnotetext{
${ }^{17}$ In his analysis of the measures taken to reduce corruption in procurement regimes, Anechiarico (2003) does. Unfortunately, this analysis only applies to selected OECD member states.
} 
In sum, it is not much of an exaggeration to argue that the literature on procurement reform in developing countries is in an embryonic state. The qualitative literature is very useful in describing reform initiatives and existing laws and practices, but tends to be country-specific. Much more needs to be documented before convincing general (that is, cross-country) lessons are likely to emerge. The current quantitative literature is at best suggestive of the benefits of procurement reforms, but would not pass serious scrutiny or convince a skeptic of the benefits of reform. Finally, the literature has only begun to address some of the newer challenges in state contracting such as electronic procurement and pressures to comply with external international rules on procurement practice (contained in regional trading agreements and existing WTO rules.)

\section{Enhancing transparency in public procurement}

Remedying the deficiencies identified above requires a substantial increase in our knowledge of state procurement policies and associated reforms. Research can play a part to improve outcomes, as can further efforts by governments to cooperate through exchanging information and sharing experiences on the efficiency and efficacy of different types of procurement practices. What follows is a description of a research program that would considerably add to the evidentiary base, and a discussion of some options for international voluntary cooperation to enhance transparency. Both could be pursued in a WTO context as a modality of continuing interchange between countries on the topic of procurement. These two elements are mutually reinforcing as the research program would help improve understanding of the role, if any, that "hard" international rules can play in encouraging the reform of state procurement practices in developing countries, and voluntary cooperation would facilitate the exchange of information and the adoption of best practices.

\section{A policy-relevant research agenda on public procurement}

The development-oriented research needed in this area has many elements, ranging from institutional and data-collection matters to rigorous empirical analyses of actual practices and the impacts of policy reforms. The following nine priority areas can be identified: 
1. First, a comprehensive list should be assembled of what policy instruments fall under the label of "public procurement policies." This may seem rather obvious to procurement experts, but to more generalist policymakers it would be helpful to clarify which governmental measures are part of public procurement policy, which measures are not, and which state agencies (in central government, in local government, and in the directly state-run industries) are supposed to implement these policies. This analysis would also be useful in delineating the scope of public procurement reform (by identifying the policy instruments that might altered) as well as providing a clear basis upon which to compare the essential features of national procurement regimes; a point developed in 2 . below.

2. Second, for as many developing countries as possible, a publicly-accessible compendium should be assembled of their public procurement laws, major pieces of implementing regulations and associated documents, and agencies responsible for administering the relevant laws. This compendium would also include key features of national procurement regulations-such as thresholds for state contracts above which competitive tendering must be used. Furthermore, the nature (if any) of any administrative or judicial oversight would be specified. Such a compendium would facilitate legitimate cross-country comparisons about the key aspects of national procurement law and its implementation.

3. Drawing upon the experiences of selected developing countries, detailed descriptions and analysis of the manner in which national public procurement systems fit into the overall public expenditure and financial management systems should be undertaken. Strong and effective financial control and accountability systems may allow for simpler procurement systems if incentives are created for efficient purchasing practices by government entities, perhaps making detailed "command and control" process guidelines/requirements redundant. Relatedly, it would be useful to evaluate the hypothesis that the greater the extent to which public entities operate in a competitive environment and are subject to hard budget constraints, the less inefficient are their purchasing decisions. 
4. Guidelines for good practices in the design of laws and implementation methods should be devised, and should include assessments of the specific procedures that are applied in different countries and mappings from existing guidelines to those recommended by major international organizations, such as the World Bank and UNICITRAL. This type of analysis should identify the important and desirable features of laws and procurement processes-including, for example, the reliance on standards and norms that apply to procedures along the lines that were developed for construction procurement in South Africa (see Watermeyer, 2004a, b). Related to this, a critical assessment of the costs and benefits of existing guidelines that are applied by institutions, such as the major development banks, would be very useful. What do these guidelines actually achieve? Are they outdated given the rise of the Internet and the potential for government to business portals to introduce market forces into the procurement process through real-time reverse auctions and the like?

5. The factual record on outcomes from procurement regimes in developing countries (including the number of contracts put out to tender, indicators of the use of selective or limited tendering, the use of preference margins in contracts, the number of firms submitting bids for a contract, the propensity to award a contract to the lowest bidder, and the propensity to source from abroad or from domestically favored groups) should be assembled. Of course, countries differ markedly in the amount of data that they collect and make available publicly, but with the growing use of computers in procurement systems, more developing countries are assembling such data. Subject to any concerns about confidentiality and the like, bringing these data together would facilitate policy analysis. Data on the observed outcomes from state procurement could be complemented by information obtained from surveys of business people and others' perceptions of the "fairness" or otherwise of national procurement systems.

6. Given the role that discriminating between suppliers for state contracts plays in many nations' procurement regimes, more research is needed that identifies the costs and benefits of such discrimination, especially as it relates to set-aside policies and to international trade. At present opinion is divided as to the merits of such discrimination. A balanced analysis and account of the pros and cons of such measures that draws upon available empirical research would help both policymakers 
and policy analysts. Another important question to be addressed is what are the most efficient ways of attaining industrial policy and equity objectives and whether public procurement is the appropriate (first best) tool available.

7. Quantitative studies on the effects of individual reform episodes in developing countries should be commissioned. After characterizing the legal and institutional nature of the reform in question, empirical analysis needs to centre on the consequences of reform. For example, to what extent does the publication of tenders increase the number of firms willing to bid for state contracts, taking into account the other factors that might determine the propensity to bid? The goal here would be to quantify the likely effect of a reform measure. Where possible, data on the fiscal outlays associated with the reform and data on any resulting fiscal savings would be presented. Ideally, at least one study should focus on a significant reform whose goal was to improve transparency, another on the effects of reducing preferences when evaluating bids, another on the procurement of goods and services that the poor are highly dependent on, and one on the strengthening the rights of firms to challenge the decisions of procurement officials. It should be stressed that the focus here would be on the quantitative impact of reforms, not on the political economy (see topic of 9 . below).

8. Drawing again on experience in developing countries, a series of studies on the linkages between procurement policies and other government policies would enhance our understanding of the connections between the procurement reforms and other directly governance-related matters. Such studies would examine the links between procurement and corruption; the implications of the growing number of prosecutions of bid-rigging cases in developing countries; and the role and relative merits of regional trading agreements, international trade agreements, and international norms (such as the UNCITRAL Model Law) in shaping procurement reform. Given the focus on transparency in discussions at the WTO, the linkages between transparencyrelated reforms and practices and corruption should be considered explicitly.

9. Finally, country-studies (or sub-national studies) of the impediments to procurement reforms and the political-economy strategies that have been deployed to overcome 
those obstacles would be very useful. Research on this front would explicitly recognize the opposition to reform and investigate what strategies were used to mitigate, ameliorate, or circumvent that opposition-including participation in international agreements, including trade agreements that cover procurement. An important question here is whether these strategies have more general application.

\section{International Cooperation on Procurement: The WTO and Transparency}

In principle, international cooperation can help improve public procurement by providing focal points for good practice and a mechanism through which governments can make binding commitments to pursue certain practices. Historically, cooperation on regulatory areas has tended to be voluntary-so-called 'soft law' - in that any agreed norms were not legally binding on signatories. Examples of specialized institutions that have been created to address specific issues abound, including the International Labour Office, the International Telecommunications Union, the Organisation for Economic Cooperation and Development, the Bank for International Settlements, and the World Customs Organization (Hoekman, 2004a). Such bodies develop consensus standards on technical issues that members agree constitute good practice, but participation and implementation is left to individual decisions by countries. Here there is generally limited scope for making implementation mandatory, and in most cases no mechanism to enforce norms through binding dispute settlement. This is a major difference with recent multilateral trade agreements, where disciplines are binding and subject to binding dispute settlement.

The focus in the WTO has traditionally been on market access. Public procurement is not subject to the GATT discipline of national treatment-members are therefore free to discriminate against foreign firms if they desire to do so. The same is true of services-the GATS excludes services procurement (Art. XIII). Only signatories to the plurilateral GPA are subject to a variety of disciplines, for both goods and services procurement, including national treatment, MFN, transparency-related provisions, and dispute settlement. ${ }^{18}$ Most developing countries have not signed the GPA, for reasons that will not be explored here. ${ }^{19}$ One result of this resistance to joining the GPA was a shift in strategy on the part of several industrialized countries-turning away from an explicit

\footnotetext{
${ }^{18}$ Coverage of services is a function of the GATS commitments that GPA members have made.

${ }^{19}$ For a discussion of this matter, see Hoekman and Mavroidis (1997).
} 
market access focus towards pushing for rules for greater transparency in government procurement. Although negotiations on transparency in government procurement practices will be kept off the table for the duration of the Doha round, the associated issues are unlikely to go away, if only because many proposed bilateral and regional trade agreements contain disciplines on these matters.

The Chairman of the WTO Working Group on Transparency in Government Procurement Practices, established after the Singapore Ministerial, identified the following twelve issues around which discussions on procurement matters at the WTO have been organized:

- definition and scope of government procurement;

- procurement methods;

- publication of information on national legislation and procedures;

- information on procurement opportunities, tendering and qualification criteria;

- time-periods;

- transparency on decisions on qualification;

- transparency on decisions on contract awards;

- domestic review procedures;

- other matters related to transparency;

- information to be provided to other governments (notification);

- WTO dispute settlement procedures; and

- technical co-operation and special and differential treatment for developing countries. $^{20}$

The proponents of more multilateral rules on transparency in government procurement include the European Communities and its Member States, the United States, Japan, the Republic of Korea, and Canada. Skeptics have included Hong Kong (China), India, and Malaysia. The published minutes of the Working Group record significant disagreements on almost each and every point, with little evidence of a convergence in views across a wide range of matters (Evenett 2003). For example, the following extract from the minutes of the 29 May 2002 meeting of the Working Group highlights the divergence of view as to the coverage of any general disciplines on transparency in government procurement:

"The representative of the European Community, joined by the representative of the United States, said that, in the absence of lists of covered entities which provided certainty about the scope and coverage of

\footnotetext{
${ }^{20}$ Successive chairmen of this Working Group have issued and updated a document titled "List Of The Issues Raised and Points Made,” from which the above 12 bullet points have been extracted.
} 
rules, a definition of government procurement was especially important in a transparency agreement. His delegation considered that, although the contours of a definition remained a matter for further discussion, any definition which was eventually arrived at should be as broad as most Members could agree to. The representative of India, joined by the representative of Malaysia, said that a wide divergence remained in the Group on the question of definition. The study phase should be used for a better understanding of the various issues related to definition. This issue should be resolved through discussions in the Working Group rather than through negotiations” (WTO 2002, page 5-6).

The matter of coverage, including potentially services and works, is important as it raises the question as to whether WTO disciplines should regulate domestic policies in ways that go well beyond market access considerations. If a broad approach to coverage were taken-i.e., general transparency disciplines applying to all procurement of goods and services, whether or not domestic policies imply that foreign firms have access - this would extend the reach of the WTO further 'behind the border'.

Moreover, a broad definition of coverage could have precedent-setting effects in the more general debate on where to draw the boundaries of the WTO. A broad approach to coverage for procurement might allow a case to be made for transparency disciplines in other policy areas-labor, environment, health, education, taxation, etc. ${ }^{21}$ Whether this is desirable depends on the preferences of members regarding the value (payoff) of extending the reach of the Dispute Settlement Understanding (DSU), as well as the effectiveness and capacity of the WTO to develop and enforce transparency disciplines. On the latter point, it is worth noting that the DSU is likely to be more effective if there are substantial "export" interests that perceive it is worth their while bringing potential cases to the attention of their home governments. In the case of transparency in government procurement, however, a proiri reasoning suggests that there will be few negative spillovers imposed on foreign firms from non-compliance with negotiated disciplines (Evenett and Hoekman 2005). Instead, domestic stakeholders will have the

\footnotetext{
${ }^{21}$ If members were to move down this path, the WTO acronym might come to stand for World Transparency Organization. It would appear there was some support within the European Commission for moving in this direction. For example, the former EC Commissioner for trade, Pascal Lamy, called for an effort to build a "broad coalition of interests" in support of an "explicit anti-corruption agenda in the WTO.” See "EU wants WTO to tackle corruption,” Financial Times January 9, 2004.
} 
greatest incentives to contest violations-suggesting domestic enforcement mechanisms will be important for effective enforcement.

\section{Beyond Transparency...or is transparency enough?}

Many of the arguments in favor of general transparency disciplines in the WTO revolve around public governance objectives, in particular reducing the scope for bribery and corruption. $^{22}$ A potential benefit arising from transparency and accountability provisions is that they may constrain rent-seeking activities. ${ }^{23}$ Although the issue of corruption extends beyond procurement, rent seeking in the public purchasing context is particularly prominent because considerable amounts of money involved are often involved. Case studies have demonstrated the cost of corruption to be high, leading to excess costs per project in the 25-50 percent range (Wade, 1982; Rose-Ackerman, 1995a). The result of corruption and rent-seeking is a reduction in the economy's growth performance as the most efficient, conforming (qualified) suppliers are not allocated contracts, resource allocation is distorted, and governments impose excess tax burdens or more commonly, pursue deficit/monetary financing (Mauro, 1995; Bardhan, 1997).

Abstracting from differences in cultural norms across countries, effective anticorruption strategies must reduce the magnitude of the benefits that can be granted by officials, increase the costs of bribery for the private sector, and limit the market power of officials (Rose-Ackerman, 1995 a,b; Bardhan, 1997). Transparency has a role to play but by itself is not sufficient. If the objective is a reduction in corruption, action needs to go further. Of the various strategies and suggestions made in the literature, the following are particularly relevant for procurement: effective deterrents through ex post punishments that exceed the gains realized (including banning firms caught in attempts to engage in bribery from bidding for contracts for a number of years); the creation of external monitoring devices and institutions (including encouragement and protection of "whistle blowers"); public transparency-enhancing mechanisms (published audits by independent auditors; a free press); privatization and hard budget constraints; requirements to encourage the use of standardized products and/or goods that have well-established market positions; and use of general retail/wholesale market prices for goods similar to

\footnotetext{
22 See, for example, Arrowsmith (1998) and OECD (2002b).

${ }^{23}$ What follows develops some of the arguments initially made in Hoekman (1998).
} 
those to be procured as comparators. In sum, transparency reforms will almost certainly have to be complemented by a variety of other actions and policies.

Moreover, to be effective transparency norms need to be enforceable. Of particular importance here are domestic challenge procedures and the costs and benefits of multilateral dispute settlement. To be effective, domestic challenge mechanisms need to provide firms with an opportunity to protest before the procurement process is completed, as well as thereafter (Alam, 1995). In the procurement context, the set of losers is usually small. In discretionary, non-transparent procurement systems losing firms have little incentive to protest against irregularities because of the power of procuring entities to black list them. In general, given the sunk costs of participation in the bidding process there is only an incentive to protest if expected returns outweigh expected costs of protesting. In the absence of effective compensation, and thus limited returns to, and incentives for, individuals bringing cases, there may be a need for public action to enforce norms and penalties that are strong enough to be of deterrent value. An ombudsman, an activist and free press, and surveys of the type discussed in section IV above, are all potential complementary mechanisms to ensure accountability.

The foregoing discussion suggests that procurement reform ought not to be limited to improving transparency - there is a plethora of complementary actions that will generally be needed on the part of governments and stakeholders. In short, from a development perspective, it is probably necessary to go beyond improving transparency alone. But this poses something of a problem in the context of trade negotiations where the natural extension of any negotiations is precisely what many WTO members are opposed to. If progress, therefore, is unlikely at the WTO, what alternatives exist for international cooperation on procurement reform?

\section{Voluntary cooperation: 'soft law' as a first step (or an end point)}

Given the uncertainty regarding the returns to multilateral rule making, one alternative way forward might be to explore the scope for more extensive voluntary cooperation between nations. ${ }^{24}$ One option could involve the creation of a mechanism through which

\footnotetext{
${ }^{24}$ It would incorrect to suggest that voluntary cooperation and norm formation in the area of government procurement is new. One prominent initiative is the United Nations Commission on International Trade
} 
countries exchange information on procurement policies, reforms, and their effectiveness on a voluntary basis. Such an approach would have several possible payoffs: (i) increased awareness of what has worked elsewhere (for example, as what types of complementary reforms may be needed, etc.); (ii) increased accountability of governments to their citizens; and (iii) to identify where there are significant cross border spillovers from policies that could justify the negotiation of international rules. Increased transparency, involving monitoring of what governments actually do, could also help mobilize support from domestic constituencies for reforms. Such monitoring or review activities should extend to the effectiveness of procurement policies in attaining the industrial development and equity-related objectives that are often spelt out in procurement legislation.

There are many options that can be pursued in implementing voluntary cooperation and greater transparency of procurement performance. One model is the Global Forum on Competition that is organized periodically by the OECD. This forum brings together competition law enforcement officials and interested officials from government ministries from OECD and non-OECD countries to share information, learn from national experiences, and identify good practice. The Asia Pacific Economic Cooperation Forum (APEC) provides another model along these lines that extends to trade and finance officials, with links to technical expertise and financial resources. The International Competition Network is another example, which differs from OECD and APEC in that the cooperation involves primarily competition stakeholders (enforcers, private practitioners), and is not inter-governmental. Here also the focus is on a cooperative effort to improve national policies and converge, where appropriate, on common standards that are applied on a voluntary basis. ${ }^{25}$

Another possibility for "soft" cooperation would be a multilateral monitoring effort. The World Bank and its partners in the wider donor community have invested

Law (UNCITRAL) Model Law on Procurement of Goods, Construction, and Services. An overview of that Model Law, including a comparison to the obligations of the current GPA, can be found in Evenett (2003). Another type of prominent international initiative on government procurement involves including provisions on procurement matters in preferential trading agreements. The latter are discussed in OECD (2002) and Evenett (2003).

${ }^{25}$ See Chayes and Chayes (1995), Abbott and Snidal (2000) and Sabel and Reddy (2002) for discussions of soft law in international relations, and Abbott (2001) for an analysis of international efforts to address corruption using this approach. 
substantial resources in assessing the performance and quality of public procurement systems in many borrower countries. The principal instrument in question is the Country Procurement Assessment Report (CPAR) - discussed briefly above. CPARs have contributed to enactment of better legal frameworks and developing new institutions to manage procurement. They could be used as an input or model for an international collaborative effort by governments to monitor their performance on the procurement front, if they are complemented by a focus on impact assessment and the collection of some of the information that is already required on the part of current GPA members (e.g., the share of procurement that is below a minimum threshold value and the share of contracts that are awarded directly without competitive bidding).

The advantages and disadvantages of this type of voluntary cooperation are well known. ${ }^{26} \mathrm{~A}$ plus is that the pace with which countries adopt policies that conform to recommended principles can vary. The 'learning' or 'focal point' models that underlie voluntary cooperation help ensure that, when implemented, policy changes are more likely to have national ownership - i.e., there are constituencies that support adoption or changes in existing practices. A downside of the voluntary approach is that insofar as there is political economy resistance to adopting national welfare-enhancing reforms, it may not happen in the first place. The same is true of policies that create negative spillovers - the incentives for countries to take the interests of partner countries into account will be weak.

In the case of procurement the weakness of the evidentiary base is such that it is hard to tell just how important these potential downsides are. As noted earlier, the adverse knock-on effects felt by foreigners of suboptimal procurement regimes in developing countries is likely to be limited, due to the small size of those countries' state budgets. In which case, the primary rationale for them to engage in international cooperation will be national; that is, improving domestic policies and performance. Even if this is not the case, a voluntary approach to specific issues that includes explicit analysis and assessment of policies will help generate information on the size and distribution of the costs and benefits of the status quo, as well as the likely net payoffs from reform. It

\footnotetext{
${ }^{26}$ See Hoekman (2004b) for more detailed discussion of soft law options in the WTO.
} 
should also reduce the uncertainty regarding the possible repercussions of subsequently signing binding commitments.

Information and analysis are important inputs into a well-functioning trading order. Greater monitoring and assessment of the impacts of policies would allow more informed and proactive engagement by civil society (think tanks, nongovernmental organizations, consumers and taxpayers) in the policy formation and negotiation process. If more is done to determine on an objective basis the effects of prevailing policies, in particular whether they are achieving stated national objectives and whether they are harming foreign commercial interests in doing so, then the case for further international rules on public procurement will become clearer.

\section{Concluding remarks}

Efficiency in government procurement is of importance in ensuring that the best value for money is obtained by public entities. Procurement practices also figure prominently in the way that many potential investors and civil society view a country. Ensuring transparency of the procurement process is an important determinant of efficiency insofar as it enhances the contestability of public procurement markets (by giving all qualified potential suppliers a chance to bid). If procurement procedures are opaque and discretionary, the incentive for firms to enter into a market are typically reduced. The same problem arises if it is possible for firms to obtain "preferred status" through bribery of officials and potential entrants do not know how to "play by the rules of the game".

Many developing countries have adopted procurement legislation and regulations that require public entities to source goods and services through an open and competitive process. To what extent actual practice is consistent with the formal rules and principles is often difficult to determine, in part because the incentives to contest violations of the formal rules of the game are often small.

A WTO agreement could provide an international mechanism through which governments credibly commit themselves to transparent procurement regimes. Whether this makes sense for individual developing countries is something that will need to be determined empirically and on a case-by-case basis. Prior discussions in the WTO Working Group on Transparency of Government Procurement Practices have revealed that many governments have doubts that there is much to be gained from further binding 
multilateral rules. Many are also concerned about the possible downside risks in terms of implementation costs and the implications of extending the DSU to procurement. There is also a systemic question insofar as the objective is limited to transparency only. Whether binding (enforceable) rules should extend to cover all procurement or only that share which is internationally contestable under existing national law is another related question.

Decisions on whether or not to extend the WTO rules to cover more elements of public procurement should be based, in part, on data and analysis. More information on both policy and outcomes in developing countries is a critical starting point towards identifying the scope and payoffs to binding international rules. The extant literature is rather limited and does not provide enough information to help policymakers identify how best to deal with procurement challenges. Development-focused research that considers the institutional environment that prevails in developing countries and links procurement concerns to the broader development agenda (priorities), complemented by a mechanism that encourages the exchange of information on outcomes and alternative policy options, could contribute towards more informed decision-making. A voluntary 'soft law' type of multilateral cooperation that aims to enhance the understanding of both applied policies and outcomes in developing countries could do much to mobilize the support needed for procurement reform. Such a process would also help identify the appropriate complementary policies that are needed to make such reforms work.

\section{References}

Abbott, Kenneth. 2001. "Rule-Making in the WTO: Lessons From the Case of Bribery and Corruption," Journal of International Economic Law, 275-96.

Abbott, Kenneth and Duncan Snidal. 2000. "Hard and Soft Law in International Governance," International Organization 53(3), 421-56.

Ades, A. and R. Di Tella. 1997. "National Champions and Corruption: Some Unpleasant Interventionist Arithmetic,” Economic Journal, 107: 1023-42.

Agaba, Edgar. 2003. "Public Procurement Reforms: Issues and Challenges: The Case of Uganda.” Paper presented to the Joint WTO-World Bank Regional Workshop on Procurement Reforms and Transparency in Public Procurement for Anglophone African Countries. Dar es Salaam, 14-17 January 2003.

Alam, M.S. 1995. "A Theory of Limits on Corruption and Some Applications," Kyklos, Vol. 48, No. 3, pp. 419-435.

Anechiarico, Frank. 2003. "Reforms in Procurement Policy and Their Prospects," in Arrowsmith and Trybus. 
Annikve, Tom. 1998. "The System of Regulation and Challenge Procedures for Public Procurement in Estonia: An Overview,” Public Procurement Law Review, vol. 7.

Arrowsmith, Sue. 1998. Towards a multilateral agreement on transparency in government procurement, International and Comparative Law Quarterly, 47: 793-810.

Arrowsmith, Sue, and Arwel Davies. 1998. Public Procurement: Global Revolution. London: Kluwer Law International.

Arrowsmith, Sue, and Martin Trybus (editors.) 2003. Public Procurement: The Continuing Revolution. Kluwer Law International.

Arrowsmith, Linarelli, and Wallace. 2000. Arrowsmith, Sue, John Linarelli, and Don Wallace, Jr., Regulating Public Procurement: National and International Perspectives. Kluwer Law International.

Bardhan, Pranab. 1997. "Corruption and Development: A Review of Issues," Journal of Economic Literature, XXXV:1320-1346.

Business News America. 2002. "Government Saved 4\% in 2001 Through E-Procurement-Brazil."

Cao, Fuguo. 2003. "China's Government Procurement Reform: From the Bidding Law to the Government Procurement Law," in Arrowsmith and Trybus.

Caron, David D. 2002. "The Structure and Pathologies of Local Selective Procurement Ordinances: A Study of the Apartheid-Era South Africa Ordinances.” University of California Public Law Research Paper No. 101. Available at www.ssrn.com

Chayes, Abram, and Antonia Handler Chayes. 1995. The New Sovereignty: Compliance with International Regulatory Agreements. Cambridge: Harvard University Press.

Choi, Imbom. 1999. "The Long and Winding Road to the Government Procurement Agreement: Korea's Accession Experience,” World Bank, mimeo.

Das, Sandwip Kumar. 2004. "India-Increased Transparency in Government Procurement Will Reduce Corruption, Is That So?” Presented at the $2^{\text {nd }}$ IWOGDA brainstorming meeting, CUTS, Jaipur June 28-29.

Ekpenkhio, Sam. 2003. "Public Procurement Reforms: The Nigerian Experience." Paper presented to the Joint WTO-World Bank Regional Workshop on Procurement Reforms and Transparency in Public Procurement for Anglophone African Countries. 14-17 January 2003. Dar Es Salaam.

European Communities. 2003. "Positive effects of transparency in government procurement and its implementation," WT/WGTGP/W/41, 17 June.

Evenett, Simon. 2003. "Is there a case for new multilateral rules on government procurement?" In SECO and Simon Evenett (eds.) The Singapore Issues and the World Trading System: The Road to Cancun and Beyond. SECO. Bern. 2003.

Evenett, Simon, and Bernard Hoekman. 2003. "Transparency in Procurement Regimes and Market Access: What can we expect from international trade agreements?” in Arrowsmith and Trybus.

Evenett, Simon, and Bernard Hoekman. 2005. "Government Procurement: Market Access, Transparency, and Multilateral Trade Rules,” European Journal of Political Economy.

Glebocki, Konrad. 2000. "An Overview of the Legal Rules Governing Public Procurement in Poland.” Public Procurement Law Review, number 3.

Hoekman, Bernard. 1998. "Using International Institutions to Improve Public Procurement," World Bank Research Observer, 13: 249-69.

Hoekman, Bernard. 2004a. "The International Trade Order: Cooperation for Economic Development", presented at the $29^{\text {th }}$ PAFTAD meeting, Jakarta December 15, 2003.

Hoekman, Bernard. 2004b. "Operationalizing the Concept of Policy Space in the WTO: Beyond Special and Differential Treatment,” World Bank, mimeo.

Hoekman, Bernard and Petros C. Mavroidis (eds.). 1997. Policy in Public Purchasing: The WTO Agreement on Government Procurement, Ann Arbor: University of Michigan Press. 
Hunja, Robert R. 2003. "Obstacles to Public Procurement Reform in Developing Countries," in Arrowsmith and Trybus.

Hupkes, Eva. H.G. 1997. "Public Procurement in Central and Eastern Europe," Public Procurement Law Review.

Khorana, Sangeeta. 2002. Accession to the Government Procurement Agreement: Implications for India. Masters Thesis. World Trade Institute.

Lamvol. 2002. Lamvol, Aleksander. "From transition to cohesion: The reform of public procurement in Estonia." Public Procurement Law Review. Number 1.

Lemke, Marian. 2003. "The Experience of Centralised Enforcement in Poland,” in Arrowsmith and Trybus.

Levy, Ricardo Pagliari. 2001. "The Law on Government Procurement in Brazil.” Public Procurement Law Review. Number 1.

Lionjanga, Armando V. 2003. Presentation to the Joint WTO-World Bank Regional Workshop on Procurement Reforms and Transparency in Public Procurement for Anglophone African Countries. 14-17 January 2003. Dar Es Salaam.

Liu, Hui. 2004. "Transparency-A Prescription to Cure Corruption in Government Procurement." Presented at the $2^{\text {nd }}$ IWOGDA brainstorming meeting, CUTS, Jaipur June 28-29.

Lovei, Laszlo, and Alastair McKechnie. 2000. "The costs of corruption for the poor." World Bank, mimeo.

Mardas, Dimitri. 2001. "Indicators for Measuring the Potential Economic Impact of Opening Government Procurement and their Application to the Situation of Hungary," Public Procurement Law Review, volume 10.

Mardas, Dimitri. and N. Varsakelis. 2000. "Public Procurement Policy and the Czech Industry." International Advances in Economic Research. Volume 6.

Mauro, P., 1998. "Corruption and the composition of government expenditure." Journal of Public Economics 69, 263-279.

McCrudden, C. 2004. "Integration of Social Policy into Sustainable Public Procurement.” April.

Moncayo, Nelson. 2004. "Government Procurement in Ecuador." Presented at the $2^{\text {nd }}$ IWOGDA brainstorming meeting, CUTS, Jaipur June 28-29.

Nkingu, Ntando. 2003 "Public Procurement Reform: The Tanzanian Experience." Paper presented to the Joint WTO-World Bank Regional Workshop on Procurement Reforms and Transparency in Public Procurement for Anglophone African Countries. 14-17 January 2003. Dar Es Salaam.

Obiri, Luke. 2003. "Public Procurement Reforms Strategy. The Kenya Experience." Paper presented to the Joint WTO-World Bank Regional Workshop on Procurement Reforms and Transparency in Public Procurement for Anglophone African Countries. 14-17 January 2003. Dar Es Salaam.

OECD. 2002a. The Size of Government Procurement Markets. Paris.

OECD. 2002b. "The Relationship Between Regional Trading Agreements and The Multilateral Trading System. Government Procurement.” 9 October 2002.

OECD. 2003. "Transparency in Government Procurement: The Benefits of Efficient Governance,” TD/TC/WP(2002)31/REV2. 14 April 2003.

Onyekpere, Eze. 2005. "Public Procurement Reforms in Nigeria." Finance CustomWire. 15 March 2005.

Orrego-Urzua, Carlos A., Claudio Osorio, and Rodrigo Mardones. 2001. "Technological innovation in public sector reform: Chile's public procurement e-system.” PREM Note No. 50, World Bank.

Ozorio de Almeida, Marcos. 2004. "Case Study on Electronic Government Procurement in Brazil," presented at the $2^{\text {nd }}$ IWOGDA brainstorming meeting, CUTS, Jaipur June 28-29.

Piasta, D. 2000. "The Approximation of Polish Law on Public Procurement to the European Directives,” Public Procurement Law Review, volume 9. 
Piselli, Elisabetta. 2003. "The Establishment and Development of a Public Procurement System for Kosovo," in Arrowsmith and Trybus.

Rose-Ackerman, Susan. 1999. Corruption and Government: Causes, Consequences, and Reform. Cambridge University Press.

Rose-Ackerman, Susan. 1995a. "The Political Economy of Corruption," Viewpoint, No. 74. Washington DC: World Bank (April).

Rose-Ackerman, Susan. 1995b. "Redesigning the State to Fight Corruption," Viewpoint, No. 75.

Rothery, Robert. 2003. "China's Legal Framework For Public Procurement." Journal of Public Procurement. Volume 3, issue 3, pages 370-388.

Sabel, Charles and Sanjay Reddy. 2002. "Learning to Learn: Undoing the Gordian Knot of Development Today,” Columbia University, mimeo (www.sopde.org/discussion.htm).

Schooner, Steven L., and Christopher R.Yulkins. 2003. "Model Behavior? Anecdotal Evidence of Tension Between Evolving Commercial Public Procurement Practices and Trade Policy,” International Trade Law and Regulation. Volume 9.

Segal, Geoffrey, and Michael Taylor. 2001. "Electronic Procurement: How Technology is Changing Government Purchasing.” E-Brief number 111. Reason Public Policy Institute.

Seong, Si Kyung, and Jae Yong Lee. 2004. "Developing e-procurement systems: a case study on the government e-procurement systems in Korea," Public Finance and Management. Volume 4(2), pages 136-166.

Srivastava Vivek. 1999. India's Accession to the GPA: Identifying the Costs and Benefits" NCAER, New Delhi.

Tian, Jingbin. 2001. "Public Procurement in China: The Way Forward.” Public Procurement Law Review, volume 10.

Tian, Jingbin. 2003. "Enforcement of Public Procurement Rules in China,” in Arrowsmith and Trybus.

Transparency International. 2002. “Karachi Integrity Pact Saves 75\% in Consulting Fees,” Press release. 27 February 2002.

Trepte, Peter. 1998. "Procurement Regulation and Emerging Economies: The Examples of Laos and Bhutan.” In Arrowsmith and Davies.

Verhage, Rob, Johan van de Gronden, Kofi Awanyo, and Samuel Boateng. 2002. "Procurement Reform in the Ghana Health Sector." Journal of Public Procurement. Volume 2, issue 2, pages 261-268.

Wade, R. 1982 "The System of Administrative and Political Corruption: Canal. Irrigation in South India,” Journal of Development Studies. Volume 18: 287-328.

Watermeyer, Ron. 2004a. "Facilitating Sustainable Development Through Public and Donor Procurement Regimes: Tools and Techniques,” Public Procurement Law Review 13(1): 30-55.

Watermeyer, Ron. 2004b. “Transparency within the South African Public Procurement System,” presented at the $2^{\text {nd }}$ IWOGDA brainstorming meeting, CUTS, Jaipur June 28-29.

Wiseman, Alan E. 2000. The Internet Economy, Access, Taxes and Market Structure. Brookings Institution Press.

Wittig, Wayne. 1999. "Building Value through Public Procurement: A Focus on Africa." International Trade Centre.

World Economic Forum (2002). Global Competitiveness Report 2001-2002. Oxford University Press, New York.

WTO (2002). World Trade Organization. "Report On The Meeting of 29 May 2002." WT/WGTGP/M/14. 13 August 2002. 
Appendix 1 Government procurement ratios in non-OECD countries, by regions

\begin{tabular}{|c|c|c|c|c|c|c|c|c|}
\hline \multirow{2}{*}{$\begin{array}{c}\text { Regions } \\
\text { General government } \\
(\% \text { of GDP })\end{array}$} & \multicolumn{4}{|c|}{ Final Consumption Expenditure (FCE) } & \multicolumn{3}{|c|}{ Total Expenditure (TE) } & \multirow{2}{*}{$\begin{array}{c}\text { GDP } \\
1998 \text { US\$ } \\
\text { Billion }\end{array}$} \\
\hline & FCE & ex. Com & ex. Def. & ex. $C \& D$ & TE & ex. Com & ex. $C \& D$ & \\
\hline \multicolumn{9}{|l|}{ Africa } \\
\hline Benin & $12.59 \%$ & & & & & & & 2.32 \\
\hline Botswana & $27.10 \%$ & & & & & & & 4.98 \\
\hline Burundi & $17.36 \%$ & & & & & & & 0.98 \\
\hline Cameroon & $10.22 \%$ & & & & & & & 8.70 \\
\hline Ivory Coast & $16.76 \%$ & $4.32 \%$ & & & $20.39 \%$ & $7.96 \%$ & & 11.10 \\
\hline Egypt & $9.45 \%$ & & & & & & & 82.71 \\
\hline Ghana & $11.88 \%$ & & & & & & & 7.17 \\
\hline Kenya & $16.27 \%$ & $3.16 \%$ & $14.43 \%$ & $2.75 \%$ & $19.17 \%$ & $6.06 \%$ & $5.66 \%$ & 10.37 \\
\hline Lesotho & $17.06 \%$ & & & & & & & 0.37 \\
\hline Madagascar & $8.25 \%$ & & & & & & & 3.75 \\
\hline Malawi & $15.31 \%$ & & & & & & & 1.69 \\
\hline Mali & $14.91 \%$ & & & & & & & 2.65 \\
\hline Mauritius & $11.73 \%$ & $3.23 \%$ & $11.37 \%$ & $3.07 \%$ & & & & 4.20 \\
\hline Morocco & $16.59 \%$ & & & & & & & 36.12 \\
\hline Mozambique & $20.18 \%$ & & & & & & & 3.82 \\
\hline Namibia & $29.33 \%$ & $9.89 \%$ & & & $35.78 \%$ & $16.34 \%$ & & 3.00 \\
\hline Niger & $17.24 \%$ & & & & & & & 2.01 \\
\hline Nigeria & $3.89 \%$ & $1.23 \%$ & & & & & & 36.14 \\
\hline Reunion & $27.35 \%$ & & & & & & & 7.25 \\
\hline Rwanda & $21.28 \%$ & & & & & & & 2.04 \\
\hline Senegal & $13.26 \%$ & & & & & & & 4.86 \\
\hline Seychelles & $28.75 \%$ & & $24.98 \%$ & & & & & 0.56 \\
\hline Sierra Leone & $7.56 \%$ & & & & & & & 0.65 \\
\hline South Africa & $19.74 \%$ & & & & $21.77 \%$ & & & 116.73 \\
\hline Swaziland & $20.80 \%$ & & & & & & & 1.18 \\
\hline Uganda & $9.10 \%$ & & & & & & & 6.06 \\
\hline Tanzania & $8.29 \%$ & & $6.74 \%$ & & & & & 8.09 \\
\hline Tunisia & $16.29 \%$ & $3.55 \%$ & & & $21.60 \%$ & $8.86 \%$ & & 20.02 \\
\hline Zambia & $19.33 \%$ & & & & & & & 3.35 \\
\hline \multicolumn{9}{|l|}{ Americas } \\
\hline Anguilla & $13.83 \%$ & & & & & & & 0.09 \\
\hline Bahamas & $14.06 \%$ & $3.42 \%$ & $13.47 \%$ & $3.27 \%$ & $14.62 \%$ & $3.98 \%$ & $3.83 \%$ & 4.12 \\
\hline Barbados & $19.75 \%$ & & & & & & & 2.33 \\
\hline Belize & $19.47 \%$ & & $18.24 \%$ & & & & & 0.67 \\
\hline Bermuda & $12.70 \%$ & & $12.48 \%$ & & & & & 2.31 \\
\hline Bolivia & $12.45 \%$ & $1.84 \%$ & & & & & & 7.96 \\
\hline Brazil & $16.46 \%$ & $7.21 \%$ & & & & & & 776.94 \\
\hline Cayman Island & $14.67 \%$ & & & & & & & 0.93 \\
\hline Chile & $9.54 \%$ & & & & $11.51 \%$ & & & 74.32 \\
\hline Colombia & $10.27 \%$ & $1.55 \%$ & $9.06 \%$ & $1.02 \%$ & $13.48 \%$ & $4.75 \%$ & $4.19 \%$ & 90.41 \\
\hline Costa Rica & $16.75 \%$ & & & & $18.36 \%$ & & & 10.42 \\
\hline Dominica & $20.16 \%$ & & & & & & & 0.25 \\
\hline Dominican Rep. & $4.23 \%$ & & & & & & & 16.04 \\
\hline Ecuador & $9.33 \%$ & $4.21 \%$ & $8.05 \%$ & $3.63 \%$ & $13.23 \%$ & $8.11 \%$ & $7.53 \%$ & 19.30 \\
\hline El Salvador & $9.74 \%$ & & & & $11.14 \%$ & & & 11.86 \\
\hline French Guiana & $34.54 \%$ & & & & $48.75 \%$ & & & 1.50 \\
\hline Greneda & $19.73 \%$ & & & & & & & 0.31 \\
\hline Guadeloupe & $30.35 \%$ & & & & $39.25 \%$ & & & 3.50 \\
\hline Guatemala & $6.34 \%$ & & & & $8.37 \%$ & & & 19.01 \\
\hline Guyana & $13.04 \%$ & & & & & & & 0.74 \\
\hline Honduras & $11.12 \%$ & & & & & & & 5.34 \\
\hline Jamaica & $7.56 \%$ & & & & & & & 7.06 \\
\hline Martinique & $28.75 \%$ & & & & $36.19 \%$ & & & 4.38 \\
\hline Panama & $16.37 \%$ & $3.72 \%$ & & & & & & 9.82 \\
\hline Paraguay & $19.33 \%$ & & & & & & & 10.93 \\
\hline
\end{tabular}

Com=Compensation of state employees

Def.=Defense expenditures

$C \& D=T o t a l$ of compesnation of state employees and defense expenditures 
Appendix 1 (continued) Government procurement ratios in non-OECD countries, by regions

\begin{tabular}{|c|c|c|c|c|c|c|c|c|}
\hline Regions & \multicolumn{4}{|c|}{ Final Consumption Expenditure (FCE) } & \multicolumn{3}{|c|}{ Total Expenditure (TE) } & \multirow{2}{*}{$\begin{array}{c}\text { GDP } \\
1998 \text { US\$ } \\
\text { Billion }\end{array}$} \\
\hline $\begin{array}{c}\text { General government } \\
\text { (\% of GDP) }\end{array}$ & FCE & ex. Com & ex. Def. & ex. C\&D & TE & ex. Com & ex. C\&D & \\
\hline Americas (continued) & & & & & & & & \\
\hline Peru & $7.94 \%$ & & & & $9.87 \%$ & & & 64.06 \\
\hline Puerto Rico & $14.12 \%$ & & & & & & & 50.51 \\
\hline Suriname & $26.27 \%$ & & & & & & & 0.82 \\
\hline Trinidad-Tobago & $16.44 \%$ & $2.59 \%$ & & & & & & 6.14 \\
\hline Uruguay & $13.70 \%$ & & & & & & & 20.95 \\
\hline Venezuela & $8.60 \%$ & $2.31 \%$ & & & $10.28 \%$ & $4.00 \%$ & & 95.02 \\
\hline \multicolumn{9}{|l|}{ Asia } \\
\hline Azerbaijan & $19.86 \%$ & $4.24 \%$ & $11.73 \%$ & $2.11 \%$ & & & & 4.10 \\
\hline Bahrain & $26.07 \%$ & & & & & & & 5.35 \\
\hline Bangladesh & $13.95 \%$ & & $12.53 \%$ & & & & & 41.42 \\
\hline Bhutan & $21.58 \%$ & & & & & & & 0.36 \\
\hline China & $12.84 \%$ & & & & & & & 960.79 \\
\hline Cyprus & $17.81 \%$ & & $13.49 \%$ & & & & & 8.88 \\
\hline Fiji & $17.44 \%$ & & & & & & & 2.33 \\
\hline Hong Kong, China & $8.69 \%$ & $2.49 \%$ & & & $11.00 \%$ & $4.81 \%$ & & 166.45 \\
\hline India & $10.54 \%$ & $3.44 \%$ & $7.42 \%$ & $1.74 \%$ & $13.29 \%$ & $6.18 \%$ & $4.46 \%$ & 420.31 \\
\hline Indonesia & $9.20 \%$ & & & & & & & 215.00 \\
\hline Iran & $11.06 \%$ & $2.63 \%$ & $8.00 \%$ & $1.90 \%$ & & & & 187.42 \\
\hline Iraq & $30.82 \%$ & & & & & & & 4.60 \\
\hline Israel & $25.95 \%$ & $10.01 \%$ & & & & & & 91.32 \\
\hline Jordan & $23.74 \%$ & & & & & & & 7.45 \\
\hline Kuwait & $37.30 \%$ & & & & & & & 26.45 \\
\hline Kyrgyzstan & $20.04 \%$ & $11.74 \%$ & & & $21.60 \%$ & $12.88 \%$ & & 1.87 \\
\hline Malaysia & $13.75 \%$ & & $10.76 \%$ & & & & & 67.48 \\
\hline Maldives & $21.97 \%$ & & & & & & & 0.40 \\
\hline Nepal & $8.72 \%$ & & & & & & & 4.48 \\
\hline New Caledonia & $33.02 \%$ & & & & & & & 3.56 \\
\hline Oman & $27.34 \%$ & & & & & & & 14.96 \\
\hline Pakistan & $12.87 \%$ & $6.61 \%$ & & & $16.29 \%$ & $10.03 \%$ & & 64.13 \\
\hline Papua New Guinea & $23.24 \%$ & & & & & & & 3.71 \\
\hline Philippines & $9.85 \%$ & $2.94 \%$ & & & $14.29 \%$ & $7.38 \%$ & & 82.24 \\
\hline Qatar & $34.44 \%$ & & & & & & & 11.70 \\
\hline Saudi Arabia & $33.86 \%$ & & & & & & & 125.84 \\
\hline Singapore & $9.35 \%$ & & & & & & & 84.38 \\
\hline Sri Lanka & $13.17 \%$ & $5.57 \%$ & $10.03 \%$ & $4.24 \%$ & $17.42 \%$ & $9.82 \%$ & $8.48 \%$ & 15.70 \\
\hline Syrian Arab R. & $14.34 \%$ & & & & & & & 64.93 \\
\hline Thailand & $9.67 \%$ & $3.08 \%$ & & & $17.31 \%$ & $10.72 \%$ & & 117.04 \\
\hline United Arab Emirates & $17.01 \%$ & & & & & & & 47.23 \\
\hline Uzbekistan & $22.71 \%$ & & & & & & & 14.19 \\
\hline Vanuatu & $28.24 \%$ & $16.86 \%$ & & & & & & 0.25 \\
\hline Viet Nam & $15.93 \%$ & & & & & & & 24.60 \\
\hline Yemen & $27.42 \%$ & & & & & & & 5.33 \\
\hline \multicolumn{9}{|l|}{ Europe } \\
\hline Albenia & $10.20 \%$ & & & & & & & 3.03 \\
\hline Belarus & $19.15 \%$ & $10.54 \%$ & $10.54 \%$ & $5.62 \%$ & $21.27 \%$ & $12.65 \%$ & $7.74 \%$ & 14.28 \\
\hline Bulgaria & $8.08 \%$ & & & & & & & 12.06 \\
\hline Estonia & $16.62 \%$ & $8.06 \%$ & $15.96 \%$ & $7.75 \%$ & $21.05 \%$ & $12.50 \%$ & $12.18 \%$ & 5.11 \\
\hline Latvia & $14.70 \%$ & $7.79 \%$ & & & $17.09 \%$ & $10.18 \%$ & & 6.19 \\
\hline Lithuania & $15.68 \%$ & & & & & & & 10.69 \\
\hline Malta & $17.56 \%$ & $4.24 \%$ & $15.20 \%$ & $3.67 \%$ & $21.87 \%$ & $8.55 \%$ & $7.99 \%$ & 3.99 \\
\hline Romania & $13.77 \%$ & & $8.49 \%$ & & & & & 41.70 \\
\hline Russia & $17.39 \%$ & & $12.70 \%$ & & & & & 283.82 \\
\hline Slovenia & $19.62 \%$ & & & & & & & 19.99 \\
\hline Ukraine & $15.77 \%$ & $7.95 \%$ & $9.33 \%$ & $4.72 \%$ & $18.15 \%$ & $10.33 \%$ & $7.10 \%$ & 42.70 \\
\hline
\end{tabular}

Notes:

Com=Compensation of state employees

Def.=Defense expenditures

$\mathrm{C} \& \mathrm{D}=$ Total of compesnation of state employees and defense expenditures 


\section{Appendix 2. World Bank Country Procurement Assessment Reports.}

Documents can be found at :http://www-

wds.worldbank.org/servlet/WDS_IBank_Servlet?ptype=advSrch\&psz=20\&pcont=results\&dt=540617

\begin{tabular}{|c|c|c|}
\hline Country & Date of report. & Report number. \\
\hline 1. Algeria. & 01.06 .2003 & 29765 \\
\hline 2. Armenia. & 01.05 .2004 & 29246 \\
\hline 3. Azerbaijan. & 01.06 .2003 & 26778 \\
\hline 4. Bangladesh. & 11.05 .2002 & 24144 \\
\hline 5. Bosnia and Herzegovina. & 30.06 .2002 & 24396 \\
\hline 6. Brazil. & 01.03 .2004 & 28446 \\
\hline 7. Cambodia. & 14.09 .2004 & 29950 \\
\hline 8. Chile. & 01.08 .2004 & 28914 \\
\hline 9. $\quad$ Colombia & $28 / 07 / 2005$ & 33260 \\
\hline 10. Cote d' Ivoire. & 10.06.2004 & 29635 (2 volumes) \\
\hline 11. Dominica. & 01.06 .2003 & 30975 (2 volumes) \\
\hline 12. Ethiopia. & 28.06 .2002 & 29057 (2 volumes) \\
\hline 13. Federal Republic of Yugoslavia. & 25.06 .2002 & 28801 \\
\hline 14. Georgia. & 30.06 .2002 & 26660 \\
\hline 15. Ghana. & 01.06 .2004 & 29055 \\
\hline 16. Ghana. & 01.06 .2003 & 29055 (5 volumes) \\
\hline 17. Guinea. & 25.06 .2002 & 26406 \\
\hline 18. Honduras & February 2005 & 32791 \\
\hline 19. India. & 10.12 .2003 & 27859 \\
\hline 20. Indonesia. & 27.03 .2001 & 21823 \\
\hline 21. Laos. & 01.10 .2003 & 25334 \\
\hline 22. Malawi. & 24.05 .2004 & 29295 (3 volumes) \\
\hline 23. Moldova. & 01.06 .2003 & 27548 \\
\hline 24. Mongolia. & 12.09 .2003 & 26985 \\
\hline 25. Nepal. & 11.04 .2002 & 23917 \\
\hline 26. Paraguay. & 01.31 .2003 & 25908 \\
\hline 27. South Africa. & 28.02 .2003 & 25751 \\
\hline 28. Tanzania. & 30.04 .2004 & 26241 \\
\hline 29. Tanzania. & 07.09 .1996 & 27940 \\
\hline 30. Timor Leste. & 23.05 .2004 & 28552 \\
\hline 31. Tonga. & 01.06 .2003 & 27342 \\
\hline 32. Uganda. & 15.06 .2004 & 32499 (3 volumes) \\
\hline 33. Uzbekistan. & 28.02.2003 & 25653 \\
\hline
\end{tabular}

